\title{
Effects of Bio Product on Rice Growth, Rice Yield and Decreases in Cadmium Contents in Soil and Rice Grains
}

\author{
Wimonrat Sitisara', Sukthai Pongpattanasiri ${ }^{1 *}$ \\ 1 School of Energy and Environmental, University of Phayao, 19, Mae Ka, Mueang Phayao District, Phayao, \\ 56000 , Thailand \\ * Corresponding author's e-mail: sukthai_p@hotmail.com
}

\begin{abstract}
The aim of this research was to study the effects of chemical $(\mathrm{CH})$ and bioproduct $(\mathrm{MIC})$ fertilizers on rice growth (plant height), rice yield (full grains), and the decrease in cadmium (Cd) contents in soil and rice grains. A silty clay loam (SCL) soil for growing rice was prepared in the laboratory, with $\mathrm{Cd}$ addition and $\mathrm{pH}$ control. The relationship between $\mathrm{CH}$ and $\mathrm{MIC}$ fertilizer additions in various amounts with the reduction in the Cd contents of soil and rice grains was explored. As a result, the rice growth in the harvest phase and the yield increased from $138.80 \pm 5.72$

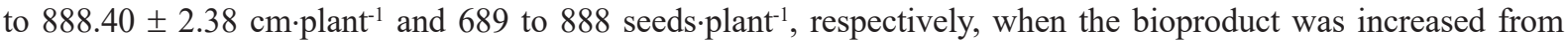
MIC100 (0.625 L·ha $\left.{ }^{-1}\right)$ to MIC500 (3.125 L·ha-1). The Cd content in the soil during the harvest phase, $35.53 \mathrm{mg} \cdot \mathrm{kg}^{-1}$, which was less than the standard value of $37.00 \mathrm{mg} \cdot \mathrm{kg}^{-1}$ defined by the Pollution Control Department (PCD), Thailand, decreased when the bioproduct increased to MIC500. For the Cd contents in polished rice grains, when MIC500 was added, $0.19 \mathrm{mg} \cdot \mathrm{kg}^{-1}$ of Cd was accumulated, which is acceptable according to the Codex Committee on Food Additives and Contaminants (CCFAC) threshold of $0.20 \mathrm{mg} \cdot \mathrm{kg}^{-1}$ for Cd. Thus, MIC500 was the most effective in reducing the $\mathrm{Cd}$ accumulation in soil and rice grains and promoting rice growth among all MIC amounts.
\end{abstract}

Keywords: bioproduct, cadmium, rice yield, rice growth.

\section{INTRODUCTION}

Cadmium (Cd) is a heavy metal that is highly toxic to human health and widely dispersed in the environment, especially in water, air and soil near the areas with chemical industries (Abdus and Bello, 2015). Cd is absorbed through the roots and then translocated to the shoots and eventually the grains of rice. The $\mathrm{Cd}$ contamination in rice grains is a serious problem, because most Asians consume rice daily. Furthermore, rice remains the main export commodity for Thailand. For this reason, Thai people and consumers of the rice grown in $\mathrm{Cd}$ contaminated soil have a greater risk of disease caused by $\mathrm{Cd}$, such as renal damage, hypertension, skeletal deformity, muscular cramps and carcinoma (Bureau of Occupational and Environmental Diseases,2018). Moreover, the $\mathrm{Cd}$ accumulation may affect the economic system of the Thailand rice market. Quality standards state that the $\mathrm{Cd}$ content in agricultural soil should be $<$
$37 \mathrm{mg} \cdot \mathrm{kg}^{-1}$ (Pollution Control Department, 2020). Important factors contributing to the $\mathrm{Cd}$ contamination of agricultural lands include proximity to/ history of mining and the use of chemical fertilizers (phosphate fertilizers), pesticides and herbicides. For example, the Mae Tao River Basin in Tak Province of Thailand has high Cd accumulation $\left(\sim 284 \mathrm{mg} \cdot \mathrm{kg}^{-1}\right)$ (Anongnat et al., 2012). In addition, $\mathrm{Cd}$ contamination was also found in rice grains in the range of 7.15-14.24 $\mathrm{mg} \cdot \mathrm{kg}^{-1}$ (Thanapat, Thongchai and Arunsiri, 2014), which is an unacceptable value. Moreover, the $\mathrm{Cd}$ accumulation in rice grains should be less than $0.20 \mathrm{mg} \cdot \mathrm{kg}^{-1}$ in accordance with the standard of the Codex Committee on Food Additives and Contaminants (CCFAC). Therefore, appropriate remediation methods are urgently needed.

Many researchers have noted that the utilization of bioproducts could be an alternative technique for the detoxification of heavy metals from polluted soils. Bioproducts are widely 
used for the treatment of soil pollution and have been adopted extensively because of their costeffectiveness and rapid implementation. Recently, Xiaoyan et al. (2016) reported that microorganisms reduced the accumulation of $\mathrm{Cd}$ in rice grains. In addition, in 2018, Quan Zhang et al. (2018) reported that Cd contamination in the soil and rice grains was reduced due to the addition of Proteobacteria and Geobacter in optimum amounts. Therefore, a bioproduct can reduce and accumulate $\mathrm{Cd}^{2+}$ ions in soil and rice grains. Moreover, Azotobacter sp. can fix nitrogen $\left(\mathrm{N}_{2}\right)$ and create antibiotic substances to inhibit the growth of fungi in the soil, aiding rice growth (Abderrahim et al., 2012). Nitrobactor sp. plays an important role in the nitrogen cycle by oxidizing nitrite into nitrate in soil, leading to the oxidation of nitrite ions $\left(\mathrm{NO}^{2-}\right)$ into nitrate ions $\left(\mathrm{NO}^{3-}\right)$, which supports plant growth (Shun et al., 2018). In addition, an essential factor for growing rice is the soil $\mathrm{pH}$. The optimum $\mathrm{pH}$ value for enzyme protease activity in Bacillus $s p$. was $\mathrm{pH}$ 8-9, and the activity was stable at alkaline $\mathrm{pH}$.

Recently, Baithong Co., Ltd. of Thailand has developed a bioproduct. Bioproducts (MICs) include many bacteria and microorganisms. Therefore, in this study, the efficiency of these bioproducts at various amounts, MIC100, MIC300 and MIC500, at reducing Cd contamination in soil and rice grains was evaluated. Moreover, the effects of these MIC contents on rice growth (plant height) and yield (full grains) were also studied.

\section{EXPERIMENTAL PROCESSES}

\section{Soil sample collection and storage}

Silty clay loam (SCL) with initial values including $\mathrm{pH}$ of 7.76, electrical conductivity of 31 $\mu \mathrm{s} \cdot \mathrm{cm}^{-1}$ and density of $1.10 \mathrm{~kg} \cdot \mathrm{cm}^{-2}$ was determined to be variable controls for this work. The organic matter $(\mathrm{OM})$ content in the soil was estimated by using the Walkley-Black technique ( $\mathrm{FeSO}_{4}$ titrations). The OM presented a high value $\left(33.10 \mathrm{mg} \cdot \mathrm{kg}^{-1}\right)$, which is above the standard value of the Food and Agriculture Organization of the United Nations (FAO) $\left(25-35 \mathrm{mg} \cdot \mathrm{kg}^{-1}\right)$. The chemical composition of the rice plants consisted of total nitrogen $(\mathrm{N})$ of $3.22 \mathrm{~g} \cdot \mathrm{kg}^{-1}$, total phosphorus $\left(\mathrm{P}_{2} \mathrm{O}_{5}\right)$ of $1.31 \mathrm{mg} \cdot \mathrm{kg}^{-1}$ and potassium $\left(\mathrm{K}_{2} \mathrm{O}\right)$ of $32.57 \mathrm{mg} \cdot \mathrm{kg}^{-1}$. Then, the soil was sieved to approximately $2.00 \mathrm{~mm}$ and packed into a zip-lock plastic bag, with $2.50 \mathrm{~kg} \cdot \mathrm{bag}^{-1}$. After that, each pseudo total soil in a zip-lock bag was mixed with a solution of $250 \mathrm{~mL}$ and soaked in the zip-lock bag for 2 weeks. In the final step, the zip-lock bag was opened and then dried, and pseudo total soil (with mixed solution) was added for 2 weeks (Wuana et al., 2010).

After 2 weeks, the dried pseudo total soil was mixed with cadmium nitrate $\left(\mathrm{Cd}\left(\mathrm{NO}_{3}\right)_{2} \cdot 4 \mathrm{H}_{2} \mathrm{O}\right)$ at a ratio of 10:1 (soil: cadmium nitrate abbreviation of Cd-soil). Then, bioproducts (microorganisms) and chemical fertilizer $(\mathrm{CH})$ were added to the Cd-amended soil.

The bioproducts had a bacterial concentration of $1.0 \times 10^{7} \mathrm{CFU} \cdot \mathrm{mL}^{-1}$ and included Achormobacter sp., Azotobacter sp., Bacillus safensis subsp. Safensis and Nitrobactor sp. The Bacillus safensis subsp. presented $16 \mathrm{~s}$ rDNA with a value of approximately $99.93 \%$. This result was confirmed by the Biodiversity Center at the Thailand Institute of Science and Technology Research.

\section{Experimental design}

The Cd-amended soil was mixed with chemical fertilizer $(\mathrm{CH})$ and bioproducts (with various minimal inhibitory concentrations; MICs). $\mathrm{CH}$ with an N-P-K ratio of 16-20-0 was applied to the Cd-amended soil at a rate of $125 \mathrm{~kg} \cdot \mathrm{ha}^{-1}$. The MICs of bioproducts from Baithong Co., Ltd. varied with the $\mathrm{pH}$ of the bioproduct solution (8.40, 8.60 and 8.81), values that did not exceed the scope of the influence of soil $\mathrm{pH}$ on nutrient availability, were as follows: MIC100, MIC300 and MIC500, with quantities of $0.625,1.875$ and $3.125 \mathrm{~L} \cdot \mathrm{ha}^{-1}$, respectively.

\section{Characterizations}

The efficiency of chemical fertilizer and bioproducts (minimal inhibitory concentrations -MICs) on rice growth (plant height) and the cadmium content in soil were examined at 3 rice development phases, including the vegetative, reproductive and harvest phases. The collected rice grain was dried at $65^{\circ} \mathrm{C}$ for $48 \mathrm{~h}$. The yield of rice (full grains) was compared with the proportion of $\mathrm{CH}$ and bioproducts added at various concentrations in the harvest phase. The available $\mathrm{Cd}$ in rice grains was estimated by atomic absorption spectrometry (AAS) with a $228.80 \mathrm{~nm}$ wavelength, $0.50 \mathrm{~mm}$ slit width and air-acetylene flame type. 


\section{RESULTS AND DISCUSSION}

Figure 1 shows the relationship of chemical and bioproduct fertilizer applications with various MIC contents from $0.625,1.875$ and $3.125 \mathrm{~L} \cdot \mathrm{ha}^{-1}$ to the height of rice plants. For the vegetative phase, the height of the rice plants was $61.80 \mathrm{~cm} \cdot$ plant $^{-1}$ with the addition of the $\mathrm{CH}$ fertilizer, but the height of the rice plants increased from 52.40 to $83.80 \mathrm{~cm} \cdot$ plant $^{-1}$ with increasing MIC fertilizer contents from 0.625 $\mathrm{L} \cdot \mathrm{ha}^{-1}$ to $3.125 \mathrm{~L} \cdot \mathrm{ha}^{-1}$ (MIC100 to MIC500). The height of the rice plants at the reproductive phase was $97.20 \mathrm{~cm} \cdot$ plant $^{-1}$ when the $\mathrm{CH}$ fertilizer was added, which was higher than that when the MIC fertilizer was added. Initially, the microorganisms in bioproducts use organic matter for growth and cell expansion. The organic matter was reduced from MIC100 to MIC500 by approximately $1.10-5.00 \mathrm{~g} \cdot \mathrm{kg}^{-1}$. At this level, microorganisms act on nitrogen fixation and digestion of soil organic matter, benefiting plant growth. The plant height in the harvest phase was $142.80 \mathrm{~cm} \cdot$ plant $^{-1}$ with the addition of $\mathrm{CH}$ fertilizer and increased from 138.80 to 160.80 $\mathrm{cm} \cdot$ plant $^{-1}$ when the MIC fertilizer contents increased from $0.625 \mathrm{~L} \cdot \mathrm{ha}^{-1}$ to $3.125 \mathrm{~L} \cdot \mathrm{ha}^{-1}$.

The yield of rice (full grains) was determined after the harvest phase, and the result is shown in Fig. 2. The 1000 grain weight results indicated that the yield components under the addition of $\mathrm{CH}$ fertilizer were significantly higher than under MIC fertilizer addition. The effect of the MIC concentrations on the yield of rice was unremarkable, which may be attributed to the microorganisms in the soil. From this result, the rice yield was significantly enhanced when MIC fertilizer was increased from $0.625 \mathrm{~L} \cdot \mathrm{ha}^{-1}$ to $3.125 \mathrm{~L} \cdot \mathrm{ha}^{-1}$ (Figure 2).

The relationships of the decreasing $\mathrm{Cd}$ concentrations and different fertilizers with the 3 growth stages, the vegetative, reproductive and harvest phases, are shown in Figure 3. The Cd concentrations in soil at the vegetative phase showed a value of approximately $93.54 \mathrm{mg} \cdot \mathrm{kg}^{-1}$ when $\mathrm{CH}$ fertilizer was added, and $\mathrm{Cd}$ concentrations rapidly decreased with MIC fertilizer addition. A slight loss of stability in $\mathrm{Cd}$ concentrations in soil due to the addition of $\mathrm{CH}$ fertilizer was observed. Xiao-Qing et al. (2016) reported that the $\mathrm{Cd}$ concentration in soil was maintained by the addition of phosphate fertilizer ( $\mathrm{CH}$ fertilizer). The increasing MICs of bioproducts from 0.625

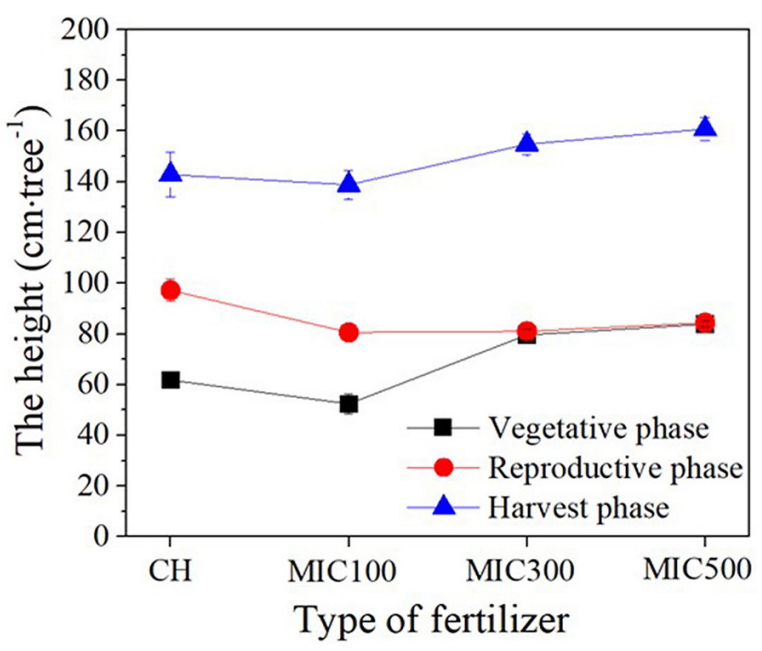

Figure 1. The relationship of chemical and bioproduct fertilizers (x-axis) and the height of the rice plants at 3 growth stages, the vegetative, reproductive and harvest phases

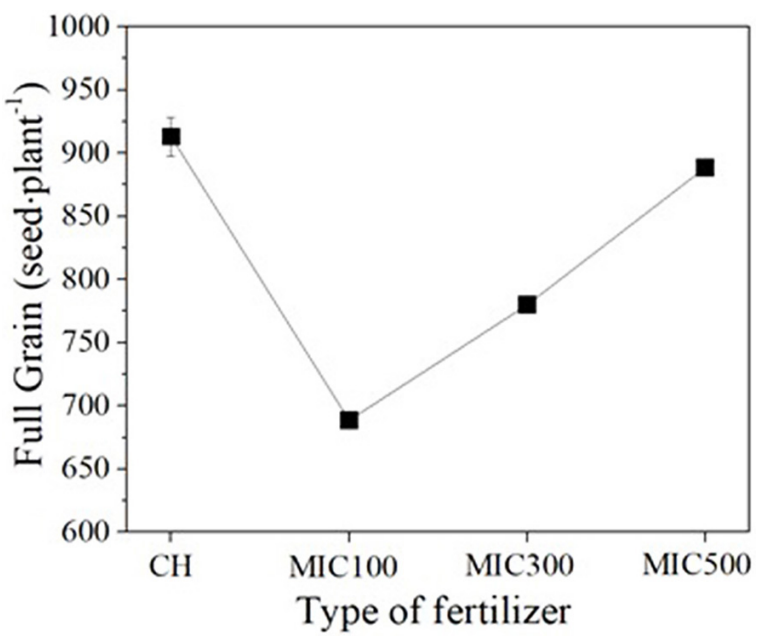

Figure 2. The 1000 grain yield of rice (full grains)

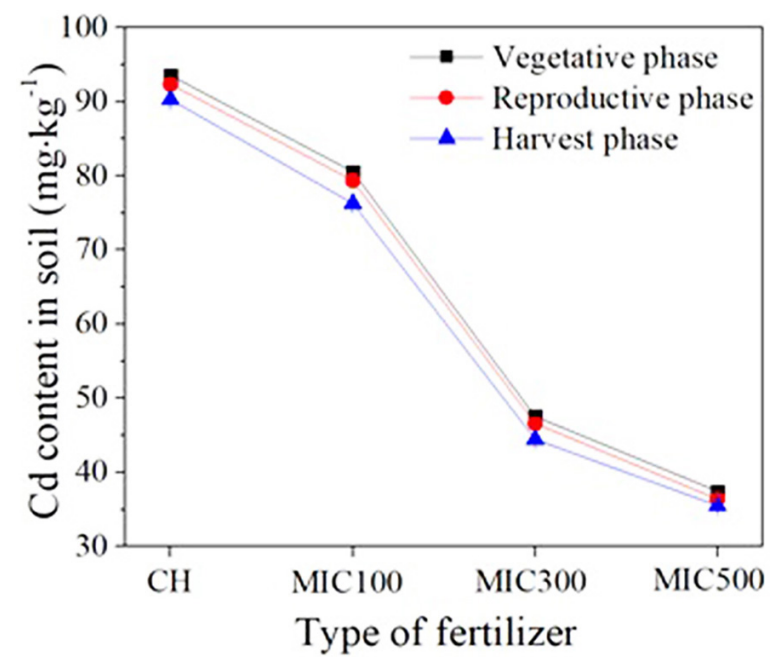

Figure 3. Cadmium concentrations $\left(\mathrm{mg} \cdot \mathrm{kg}^{-1}\right)$ in soil under different fertilizers 
$\mathrm{L} \cdot \mathrm{ha}^{-1}$ to $3.125 \mathrm{~L} \cdot \mathrm{ha}^{-1}$ led to a continuous decrease in Cd concentrations from 80.55 to 37.48 $\mathrm{mg} \cdot \mathrm{kg}^{-1}$, respectively. In the reproductive phase and harvest phase, the $\mathrm{Cd}$ concentrations tended to be the same as those in the vegetative phase. At the harvest phase, MIC500 addition resulted in the $\mathrm{Cd}$ concentrations of $35.53 \mathrm{mg} \cdot \mathrm{kg}^{-1}$, which is lower than the standard value $\left(37.00 \mathrm{mg} \cdot \mathrm{kg}^{-1}\right)$ defined by the Pollution Control Department; PCD, Thailand. The decreasing $\mathrm{Cd}$ concentrations associated with the different fertilizers were $\mathrm{CH}>$ MIC100 > MIC300 > MIC500.

The relationships of the decreasing Cd concentrations and different fertilizers with the harvest phase are shown in Figure 4. In the present study, the $\mathrm{Cd}$ content in polished rice grains significantly decreased when the type of fertilizer was changed from $\mathrm{CH}$ to MIC. The Cd concentration under $\mathrm{CH}$ fertilizer was $0.51 \mathrm{mg} \cdot \mathrm{kg}^{-1}$, which is high and presents health risks. For bioproducts, the $\mathrm{Cd}$ concentrations continuously decreased from 0.45 to $0.19 \mathrm{mg} \cdot \mathrm{kg}^{-1}$ when MICs increased from MIC100 to MIC500. Thus, the addition of MIC500 (3.125 L.ha- $\left.{ }^{-1}\right)$ led to a Cd value of 0.19 $\mathrm{mg} \cdot \mathrm{kg}^{-1}$, which was lower than the standard value of $0.20 \mathrm{mg} \cdot \mathrm{kg}^{-1}$ defined by the Codex Committee on Food Additives and Contaminants (CCFAC). Yuling et al. (2018) compared the amount of $\mathrm{Cd}$ accumulated in rice and found that rice grains grown in soil containing bacteria were lower than those grown in soil that did not contain bacteria. In the experiment, the plants were grown at 0.1 $\mathrm{mg}$. $\mathrm{kg}^{-1}$ and had maximum biosorption capacities of $31.95 \mathrm{mg}$. $\mathrm{g}^{-1}$ and $24.01 \mathrm{mg}$. $\mathrm{g}^{-1}$, respectively.

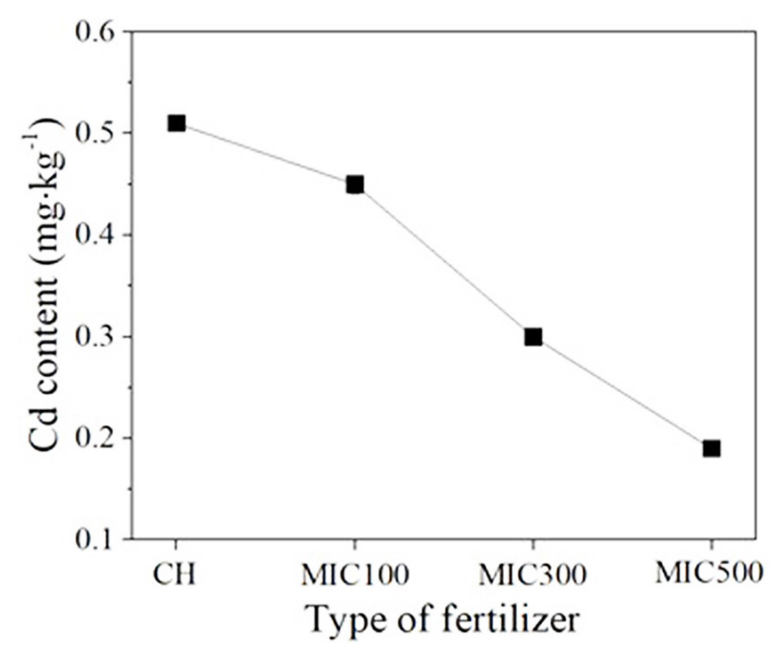

Figure 4. Cadmium concentration $\left(\mathrm{mg} \cdot \mathrm{kg}^{-1}\right)$ in polished rice under different fertilizers
Decreased Cd contents associated with different fertilizer and microorganism contents may be the result of inhibition of the enzymes responsible for increasing the $\mathrm{Cd}$ contents. This result suggests that MIC fertilizer has much greater influence on the decrease in $\mathrm{Cd}$ in soil and rice grains than $\mathrm{CH}$ fertilizer at all concentrations.

\section{CONCLUSIONS}

This study highlights the effects of chemical fertilizer and bioproducts on rice growth (plant height), yield (full grains), and the decrease in cadmium contents in soil and rice grains. The results showed that the highest number of rice plants in the harvest phase was observed with the addition of MIC500. For the yield of rice (full grains in 1000), the addition of $\mathrm{CH}$ led to good growth of rice grains, indicated by $\geq$ 900 full grains in 1000 grains. The lowest Cd contamination in soil and polished rice grains was exhibited when MIC500 was added. The $\mathrm{Cd}$ contents in the soil and polished rice grains decreased by $35.53 \mathrm{mg} \cdot \mathrm{kg}^{-1}$ and $0.19 \mathrm{mg} \cdot \mathrm{kg}^{-1}$, respectively, which are levels lower than those outlined by the Pollution Control Department (PCD), Thailand, for the soil and the Codex Committee on Food Additives and Contaminants (CCFAC) for rice grains.

\section{Acknowledgements}

This research has been funded by the Research and Researchers for Industrial (RRI) under the operation of the Thailand Research Fund (TRF) and Baitoung Company Limited.

\section{REFERENCES}

1. Aasfar A., Bargaz A., Yaakoubi K., Hilali A., Bennis I., Zeroual Y., Kadmiri I.M. 2021.Nitrogen Fixing Azotobacter Species as Potential Soil Biological Enhancers for Crop Nutrition and Yield Stability. frontiers in Microbiology, 12, 1-19.

2. Abdus-Salam N., Bello M. 2015.Kinetics, thermodynamics and competitive adsorption of lead and zinc ions onto termite mound. International Journal of Environmental Science and Technology, 12, 3417-3426.

3. Bureau of Occupational and Environmental Diseases. 2018. Situation report: Diseases and health hazards from work and environment in 2017. 
Nonthaburi: Department of Disease Control, Ministry of Public Health. (in Thai)

4. Han S., Zeng L., Luoa X., Xiong X., Wen S., Wang B., Chen W., Huang Q. 2018. Shifts in Nitrobacterand Nitrospira-like nitrite-oxidizing bacterialcommunities under long-term fertilization practices. Soil Biology and Biochemistry, 124, 118-125.

5. Lin X., Mou R., Cao Z., Xu P., Wu X., Zhu Z., Chen M. 2016. Characterization of cadmium-resistant bacteria and their potential for reducing accumulation of cadmium in rice grains. Science of the Total Environment, 570, 97-104.

6. Liu Y., Tie B., Li Y., Lei M., Wei X., Liu X., Du H.2018. Inoculation of soil with cadmium-resistant bacterium Delftia sp. B9 reduces cadmium accumulation in rice (Oryza sativa L.) grains. Ecotoxicology and Environmental Safety, 16, 223-229.

7. Nobuntou W. 2010. Effects of heavy metals in organic materials on soil and plant quality. Soil Science Research Group Agricultural Production Research Bureau Department of Agriculture. Thailand, 1-84. (in Thai)

8. Pluemphuak T., Mala T., Kumlung A. 2014.Cadmium Contents in Rice Grown in Cd Contaminated
Paddy Fields in Mae Tao Floodplains Tak Province Thailand. Journal of Science and Technology, 2638. (in Thai)

9. Pollution Control Department. 2020. Soil quality standards for agriculture. Bangkok : Department of Pollution Control Department, Ministry of Natural Resources and Environment. (in Thai)

10. Sriprachote A., Kanyawongha P., Ochiai K., Ma T. 2012.Current situation of cadmium-polluted paddy soil, rice and soybean in the Mae Sot District, Tak Province, Thailand. Soil Science and Plant Nutrition, 270, 349-359.

11. Wuana R.A., Okieimen F.E., Imborvungu J.A. 2020. Removal of heavy metals from a contaminated soil using organic chelating acids. Environ. Sci. Tech, 7, 485-496.

12. Xiao Q.H. et.al. 2018. Release of cadmium in contaminated paddy soil amended with NPK fertilizer and lime under water management. Ecotoxicology and Environmental Safety, 159, 38-45.

13. Zhang Q., Zhang L., Liu T., Liu B., Huang D., Zhu Q., Xu C. 2018.The influence of liming on cadmium accumulation in rice grains via iron-reducing bacteria. Science of the Total Environment, 645, 109-118. 